\title{
Soil Depletion
}

\author{
Sezer Göncüoğlu \\ 403 S. Allen Street, State College 16801, Pennsylvania, United States
}

\begin{abstract}
Soils are under threat around the world. Erosion, pollution, salinization and acidification degrade soils irreversibly. Evidently, the rate of soil degradation greatly exceeds the rate of soil formation. In some countries, soil lost is almost 100 times faster than the rate of its formation. Therefore, soil needs to be considered as a nonrenewable resource. Incessant construction activities along with unsustainable mining operations and energy-related undertakings in recent years have accelerated the degradation of soil in Turkey. Highway travellers can witness the mindless plunder all over the land. As one travels smoothly on newly constructed highways, looming along the roads are piles of leftover destruction: heaps of broken asphalt from previous roads; newly excavated topsoil dumped into adjacent streams; eroded hillsides. In the age of global climate change, these so-called development efforts sound incomprehensible since such anthropogenic activities exacerbate the change. Clearly, climate change increases the erosion rates and reduces the soil quality. This fact alone requires each country to adopt and implement sound conservation practices to protect their soils, and hence, social stability and security. The most effective way to conserve soil is to establish and maintain ground cover vegetation. Avoiding unnecessary soil sealing also conserves soil.
\end{abstract}

Key words: Soil, degradation, erosion, global climate change.

\section{Introduction}

One can see the traces of future catastrophic events in anthropogenic soil degradation. Erosion is a major concern. Although geologic erosion is a relatively slow process, human activities such as farming, mining, logging and construction speed up this process. Soils are also being degraded as a result of salinization, acidification, and pollution. About 3.5 billion ha of land area has been affected by soil degradation-by erosion, salinization, acidification and pollution [1]. Other threats to world soils include compaction by heavy machinery and sealing by human made structures [2, 3]. This paper elaborates mainly on soil erosion, setting soils of Turkey as an example. Soil sealing is also mentioned briefly.

Soil is a product of both geologic and biologic processes, which take place slowly over geological time periods. Soil formation starts with weathering of rocks through physical and chemical processes. Rocks are broken down by sunlight, air and water, producing

Corresponding author: Sezer Göncüoğlu, Ph.D., freelance social science researcher, research field: environmental sociology. E-mail: sgoncuoglu@gmail.com. soil precursors. Algae, fungi, lichens, mosses and herbaceous and woody plants affect these soil materials and leave organic waste and nutrients behind. Soil formation is a slow process. $2.5 \mathrm{~cm}$ of topsoil may form in 1,000 years [4]. Nonetheless, the rate of soil formation varies across geographic regions according to the composition of parent rock, the annual amount of precipitation, annual average temperature, the kind and amount of vegetation, and topography. These factors also affect the kind of soil that is formed.

Soil supports life on earth. It is a living ecosystem that contains billions of bacteria, fungi and other microbes, which sustains plants, animals and humans. Soil is an ecological and hydrologic resource. It stores carbon, filters water, sustains ecosystems and provides food, fiber and fuel $[2,5,6]$. Yet this most fundamental resource is under serious threat around the world. "Sadly, soil formed on a geological time scale is being removed on a human time scale" [7]. For this reason, soil needs to be considered as a nonrenewable resource [8]. 


\section{Soil Degradation}

Erosion is a significant threat to soil health. Plants protect the soil from wind and water erosion, supporting biological diversity. As long as the rate of erosion does not exceed the rate of soil formation, topsoil continues to accumulate, supporting even more vegetation [7]. But if it does, soil quality starts to decline. Erosion removes mineral- and nutrient-rich topsoil and leads to a decline in biological productivity [9]. As organic matter and nutrients go away, water-holding capacity of the soil also declines. Land degradation starts when fine soil particles are carried away by water and wind since these particles contain more nutrients than coarse particles [10]. In some countries, soil loss is almost 100 times faster than the rate of its formation [2]. Wind and water erosion removes 75 billion tons of soil from the land every year [4].

Soil erosion is a major threat to ecological and societal wellbeing. Erosion-(1) destroys ecosystems; (2) decreases agricultural productivity; (3) reduces the water quality because of sediment and pollutant transportation; (4) diminishes the amount of water that infiltrates in the soil; (5) causes sedimentation in river channels and sewage systems; and (6) leads to muddy flooding, which damages infrastructure and private property.

Agriculture, deforestation, mining, haphazard construction activities and overgrazing are the main drivers of soil degradation. Excessive tillage in agriculture is known to be the main driver of wind and water erosion. Large-scale erosion, decreased rainfall retention and increased runoff may eventually lead to desertification in semi-arid and arid lands. The United Nations announced in 2010 that desertification affects $25 \%$ of the earth's land area [6]. According to UNCCD (United Nations Convention to Combat Desertification), desertification threatens the livelihoods of 1.5 billion people globally.

Dust storms are visible indicators of soil erosion. Once vegetation is removed from the soil, small soil particles are blown away by the wind. These particles can remain airborne over great distances. After fine soil particles are all gone, larger particles remain behind. Then sand storms begin. Sand storms are the final phase in desertification process [7]. Giant dust bowls are historically new, which results mostly from a combination of human activities, such as overgrazing of grasslands, over-plowing of agricultural lands and overcutting of forested areas [7].

Steinbeck [11] chronicled the 1930s Dust Bowl of the United States in the "The Grapes of Wrath", which resulted from over-plowing of vast areas of grassland. Kazakhstan experienced the same predicament in the late 1960s [12]. The reason was also over-plowing of grassland: 40 million ha of grassland was over-plowed to grow grain in 1950s and 1960s. Nearly half of the land was degraded by wind erosion once the area was hit by a drought in 1965. In China, $90 \%$ of grassland was degraded because of overgrazing [12]. Today, $25 \%$ of China's land area is covered by desert that harbors dust storms each spring, the effects of which can extend as far as North America. And there are the deserts of Africa, which were formed by combined effects of overgrazing and drought. These deserts are the largest source of dust in the atmosphere.

Global climate change exacerbates the extant soil degradation and desertification. Heavy downpours, increased precipitation, and higher temperatures are expected in the future because of global climate change. Droughts are forecasted to become more pronounced as the earth warms. As the ground warms up, organic matter decomposes more readily, reducing soil fertility and increasing erosion. At the same time, decomposition releases carbon dioxide and other greenhouse gases into the atmosphere, fueling global warming. Mitigating the adverse effects of global climate change requires sound practices for natural resource conservation.

Soil erosion intensifies on sloping lands where each degree of slope causes more surface soil to be eroded [13]. Land disturbing activities on steep-slope mountains have the potential to induce landslides that 
pose serious threat to public safety. Such activities also increase stream sedimentation and reduce groundwater replenishment. In March 2014, a deadly mudslide happened in Oso, Washington in the United States, and 42 people died. Before the landslide, the area received twice the average rainfall. Also, a small earthquake occurred. But a major reason for the mudslide was the excessive logging of the ancient Douglas fir trees for many years [14]. There was nothing to hold the land in place during heavy rainfall. Jackson, Wyoming, a resort town in the United States, also faces a massive landslide. Geologists [15] indicated that a combination of land development, historic excavation and moisture from snowmelt and rainfall weakened the rock formations, setting the stage for their collapse. Shortly before the landslide became observable, the area was graded for roads and buildings that could have weakened the hillside.

Such events should not be taken solely as natural disasters. To some extent, they are considering that global warming has changed the amount and intensity of rainfall in many parts of the world. Yet global warming is a human induced phenomenon itself. Disasters are joint products of natural events and human activities. Natural events cannot be prevented but disasters can. Both flood events and landslides are predictable and foreseeable. Societies create their own vulnerabilities.

Senseless development efforts either leave the soil barren or seal it, and both are problematic. Soil sealing is quite common in cities. Sealing of the soil with asphalt and concrete materials creates impervious surfaces, which prevent rainfall from percolating into the ground. Lack of permeable surface also makes cities vulnerable to flood events. Of course, building on floodplains should not be overlooked, and it is a major cause of floods. As buildings rise up on floodplains, cities struggle with "floods that bring no richness to the land and steal what little richness is there"-as Steinbeck indicated in the "The Grapes of Wrath" [11]. Resource use has been intensified because of population growth and new needs. Yet how resources are used is critically important. Felling of trees, building on floodplains, exposing the soil or sealing it are all likely causes of soil degradation. Soil degradation and desertification threaten global public health and jeopardize biodiversity. Degraded soil means soil that is no longer available for food production [8]. Countries lose the capacity to feed themselves as they lose their topsoil [6].

\section{Soils of Turkey}

Turkey is among those countries the soils of which are very degraded [2]. Despite this fact, soil degradation takes place incessantly in every corner of the country. Construction activities along with unsustainable mining operations and energy-related undertakings in recent years accelerated the degradation of soil. Countryside, which was once bountiful farmland, has been ravaged by a colony of quarries and mines. Highway constructions have also been extended toward unspoiled rural land. Indeed, highway travellers can witness the mindless plunder all over the land. One travels smoothly on newly constructed highways while observing piles of leftover destruction everywhere: heaps of broken asphalt from previous roads; newly excavated topsoil dumped into adjacent streams; eroded hillsides; quarries on the horizon. The topography of Turkish countryside is irreversibly changing. In cities, public housing and shopping center constructions prevail. All that has brought damages to the environment and created problems for people who have lived on these lands for ages. Besides, trash is mounting everywhere in countryside, such as plastic water bottles, aluminum cans, plastic shopping bags, concrete debris from demolished buildings, asphalt blocks from road constructions, glass, and so on. In the age of global climate change, these so-called development efforts sound incomprehensible since such anthropogenic activities are responsible for the change in the first place. 
Large tracts of land in Turkey are confronted with intense soil erosion. Because of its topographical attribute that is characterized by steep slopes, about $77 \%$ of the country's soils are naturally prone to erosion [16]. Steep slopes, especially if they are barren, create runoff conditions with heavy rains and cause soil erosion problems. Leaving steep slopes mostly untouched and keeping a cover of vegetation on them would control soil erosion to a large extent. Yet in many regions of Turkey, ongoing constructions of inter-city highways and hydroelectric power plants leave steep slopes barren. Hillsides along hundreds of kilometers of highways in Turkey are disturbed. Some hillsides are covered with steel cages, some are sealed with sprayed concrete, and some are supported with stonewalls, most of which gave way in heavy rains, and all are pitiful attempts. Man-made structures often fail to hold the soil in place against the workings of wind, water and gravity. The most effective way to protect barren hillsides is to plant on them. A dense, robust cover of vegetation is the best protection against soil erosion on the hillsides.

Leaving soil exposed creates not only erosion but also various pollution problems. Construction projects may unearth natural deposits of acid-forming minerals if proper precautions are not taken. An example of what exposed mineral deposits might cause in the environment occurred in State College, Pennsylvania in the United States. A highway construction project unearthed a natural deposit of acid-forming pyritic rock, which went unnoticed for a long time [17]. Excavated rock was crushed and used as a road base and fill before its nature was discovered. Within months, metal-laden water infiltration and surface runoff from the exposed pyrite vein and crushed rock piles created serious acidification and contamination problems in nearby high-quality streams and groundwater. Residential water supply wells were also impacted. Highway construction was suspended for many months to find a proper way to neutralize the extensive acidification and heavy metal contamination in the surrounding area.
During this time, mountains were sealed with heavy plastic covers to minimize water infiltration in the soil and surface runoff.

The 2004 Nobel Peace Prize Laureate Wangari Maathai addressed the Kenyan soldiers on one occasion and said: "[You] are trained to protect the borders of the country. [You] hold your gun, what are you protecting? The whole country [soil] is disappearing with the wind and the water. When you look at the rivers and they are brown, that is your country disappearing.". To protect Kenyan soil from further degradation, Wangari Maathai mobilized women around The Green Belt Movement in 1977 to plant trees around the country [18].

What Maathai pointed to in Kenya was materialized in Bodrum in March 2014: the color of the sea turned to brown when 2 days of rainfall caused large quantities of soil to be carried by streams from the barren mountains. In April 2014, the Asian side of the Dardanelles Strait also turned brown after a heavy downpour because of soil carried by the Sarıçay River, which runs through Çanakkale. Indeed, floods have become a common event in Turkish cities. On June 4, 2014, the sea merged with the land in İstanbul when the city was flooded after a heavy rainfall. On June 6, 2014, the residents of Zonguldak and Bartın, two cities along the Black Sea Coast, were struggling against muddy floodwater. On the same day, inter-city highway was shutdown in Düzce because of mud flood caused by heavy rainfall. At the same time, inner city was flooded as a result of the overflow of the nearby creeks.

\section{Protecting the Soil}

Soil needs to be protected as a non-renewable resource because the rate of soil degradation greatly exceeds the rate of its formation. Soil degradation reduces agricultural productivity, threatens crop yield, hence food security. Soil management needs to be an intrinsic part of development issues such as food security and biodiversity protection. It provides the best tool to handle the challenges of climate 
change [19].

Land areas covered with vegetation are more resistant to water and wind erosion [12]. Plant biomass provides a protective layer for soil. Soil sustains vegetative cover, which, in turn, protects the soil from erosion. Vegetative cover also-(1) permits the accumulation of topsoil; (2) prevents soil particles from creating an impermeable layer by binding together (surface capping); (3) facilitates the aeration of soil; (4) makes the soil more resistant to rainfall runoff; and (5) allows more rainfall to infiltrate the ground, replenishing groundwater. Trees are especially important as vegetative covers since their root systems have the highest potential to hold soil in place.

Government initiative plays an important role in soil protection. Georgia has been experiencing a serious soil erosion problem because of the combined effects of strong mountain winds and lack of rainfall. Over-forestation and over-grazing in the past created this problem. Even though Georgia's soil is rich in minerals, erosion reduced harvests up to $40 \%$. Currently, with government support, Georgian farmers try to combat erosion with the help of German farmers [20]. In Algeria, the government supports planting of perennials such as fruit orchards, olive orchards, and vineyards - crops that can help keep the soil in place [6]. In contrast, the government of Turkey is in the process to lift a law that protects olive groves for the benefit of energy-related investments.

Protecting agricultural land is essential. Unfortunately, Turkey lost $10 \%$ of its farmland between 2002 and 2012 according to the TÜIK (Turkish Statistical Institute) data. In 2002, the country had 26.5 million ha of farmland; and in 2012, the country had 23.7 million ha of farmland. Even though agriculture is considered to be the primary cause of soil degradation (erosion, pollution and compaction), it does not necessarily have to be practiced as such. Sustainable agriculture protects and replenishes the soil, preserves biological diversity and provides habitat for wildlife. Such farming practices as no-till/low-till, cover crops, diversified crop rotations, livestock-integrated farming, and growing trees for a riparian buffer along streams proved to be beneficial soil protection practices. Such practices also improve ecological biodiversity.

In cities, soil sealing needs to be minimized. Soil management should be directed toward the preservation of existing green spaces and establishment of new ones [4]. Vacant lands can be secured as green spaces, either as community gardens or public parks. As Alexander et al. [21] recommended, decision makers could "define all farms as parks, where the public has a right to be; and make all regional parks into working farms".

\section{Conclusion}

Soil is the basis of existence on earth. Soil formation from hard rock takes about 1,000 years. Yet human activities degrade this most fundamental resource faster than its formation. Soil degradation is a global problem. Human induced global climate change accelerates the degradation of world soils. The main threats to soils are erosion, salinization, acidification, pollution, sealing and compaction.

In Turkey, large tracts of land are being severely disturbed either by exposing the soil or sealing it. Extensive highway constructions and quarries often leave denuded landscapes behind, which cannot support any vegetation. Agriculture, which is considered as the primary cause of erosion and non-point pollution, seems to be agreeable in Turkey, compared to hundreds of quarries cutting through mountain forests. At least, agriculture can be improved by employing sustainable farming practices. Quarries and large-scale construction activities deforest lands and accelerate natural erosion, clogging streams with sediments and acid. It should be noted here that quarries in Turkey were excluded from environmental impact assessment in 2004 with a change made in Mining Law. 
The importance of vegetation has long been recognized in soil conservation. The most effective way to conserve soil is to establish and maintain ground cover vegetation. Avoidance of unnecessary soil sealing has also been proven to be conducive to both soil and water conservation.

\section{References}

[1] Bai, Z. G., Dent, D. L., Olsson, L., and Schaepman, M. E. 2008. "Proxy Global Assessment of Land Degradation." Soil Use and Management 24 (3): 223-34.

[2] Banwart, S. 2011. "Save Our Soils." Nature 474 (7350): 151-2.

[3] Batey, T., and Mc Kenzie, D. C. 2006. "Soil Compaction: Identification Directly in the Field." Soil Use and Management 22 (2): 123-31.

[4] Pimentel, D., Harvey, C., Resosudarmo, P., Sinclair, K., Kurz, D., McNair, M., Crist, S., Shpritz, L., Fitton, L., Saffouri, R., and Blair, R. 1995. "Environmental and Economic Costs of Soil Erosion and Conservation Benefits." Science 267 (5201): 1117-23.

[5] Knox, E. G., Bouchard, C. E., and Barrett, J. G. 2000. "Erosion and Sedimentation in Urban Areas." In Managing Soils in an Urban Environment, edited by Brown, R. B. Madison: American Society of Agronomy.

[6] Stocking, M. A. 2006. "Tropical Soils and Food Security: The Next 50 Years." In State of the Planet 2006-2007, edited by Kennedy, D., and the editors of Science. Washington DC: Island Press.

[7] Brown, L. R. 2011. World on the Edge: How to Prevent Environmental and Economic Collapse. New York, NY: W. W. Norton \& Company.

[8] Evans, C. V., Fanning, D. S., and Short, J. R. 2000. "Human Influenced Soils." In Managing Soils in an Urban Environment, edited by Brown, R. B. Madison: American Society of Agronomy.

[9] Wackernagel, M., and Rees, W. 1996. Our Ecological Footprint: Reducing Human Impact on the Earth. Gabriola Island, British Columbia, Canada: New Society Publishers.

[10] Wang, X., Chen, F., and Dong, Z. 2006. "The Relative Role of Climatic and Human Factors in Desertification in
Semiarid China." Global Environmental Change 16: 48-57.

[11] Steinbeck, J. 2006. The Grapes of Wrath. New York, NY: Penguin Books.

[12] Larsen, J. 2012. "Modern-Day Dust Bowls Devastate Regions throughout the World." Earth Policy Institute. Accessed June 21, 2014. http://ecowatch.com /2012/12/21/dust-bowls-devastate/.

[13] Pimentel, D., and Burgess, M. 2013. "Soil Erosion Threatens Food Production." Agriculture 3: 443-63. Accessed June 23, 2014. http://www.mdpi. com/20770472/3/3/443/htm.

[14] Baker, M., Armstrong, K., and Bernton, H. 2014. "State Allowed Logging on Plateau above Slope." The Seattle Times. Accessed June 26, 2014. http://seattletimes. com/html/localnews/2023225363_mudslideloggingxml.ht $\mathrm{ml}$.

[15] Brown, M. 2014. "Slow-Moving Landslide Devouring Part of Wyoming Town." Accessed June 26, 2014. http://www.huffingtonpost.com/2014/04/20/hungry-wyo ming-landslide-eating-town_n_5182520.html.

[16] Kapur, S., Akça, E., Özden, D. M., Sakarya, N., Çimrin, K. M., Alagöz, U., Ulusoy, R., Darıcı, C., Kaya, Z., Düzenli, S., and Gülcan, H. 2008. "Land Degradation in Turkey." Accessed May 14, 2014. http://www. scribd.com/doc/2553149/Land-Degradation-in-Turkey.

[17] ITRC (Interstate Technology and Regulatory Council). 2010. "I-99 Remediation Site, Centre County, Pennsylvania." ITRC. Accessed April 24, 2014. http://www.itrcweb. org/miningwaste-guidance/cs5_i_99.htm.

[18] Curwood, S. 2012. "Nobel Prize Winner Wangari Maathai Remembered." Living on Earth. Accessed March 12, 2014. http://www.loe.org/blog/blogs.html/? seriesID $=1 \& b \log I \mathrm{D}=20$.

[19] Lal, R., Delgado, J. A., Groffman, P. M., Millar, N., Dell, C., and Rotz, A. 2011. "Management to Mitigate and Adapt to Climate Change." Journal of Soil and Water Conservation 66 (4): 276-85.

[20] Deutsche, W. 2012. "United against Soil Erosion: German Farmers in Georgia." Accessed March 14, 2014. http://georgien.blogspot.com.tr/2014/06/global-3000-unit ed-against-soil-erosion.html.

[21] Alexander, C., Ishikawa, S., and Silverstein, M. 1977. A Pattern Language. New York, NY: Oxford University Press. 